\title{
A Contribution to the Chemical Characterization of Rivers in the Rio Negro Basin, Brazil
}

\author{
Ivo L. Küchler ${ }^{a^{*}}$, Norbert Miekeley ${ }^{b}$ and Bruce R. Forsberg ${ }^{c}$ \\ ${ }^{a}$ Analytical Chemistry Department, Fluminense Federal University, 24020-150, Niterói - RJ, Brazil \\ ${ }^{\mathrm{b}}$ Chemistry Department, Pontifical Catholic University, 22453-900, Rio de Janeiro - RJ, Brazil \\ ${ }^{c}$ Ecology Department, National Institute for Amazonian Research, 69011-970 - Manaus - AM, Brazil
}

\begin{abstract}
Amostras de água foram coletadas no Rio Amazonas, no Rio Negro (Brasil) e em 17 afluentes do Rio Negro, na Amazônia Central. As análises consistiram em medidas de pH, condutividade, carbono orgânico (DOC) e espectrometria de massas com fonte de ICP. Através da análise multivariada as variáveis foram classificadas em três fatores, correspondentes a $94 \%$ da variância. O gráfico de escores de fatores mostrou que a maioria das amostras da Bacia do Rio Negro formam um grupo homogêneo. Testes de ultrafiltração confirmaram que o Rio Negro apresenta compostos orgânicos de massa molecular mais alta que o Rio Solimões, e que alguns metais encontram-se associados com estes compostos. Observou-se também que, nas águas da maioria dos rios da Bacia do Rio Negro, os elementos pesados das Terras Raras estão enriquecidos em relação aos elementos leves, enquanto o contrário ocorre no material particulado.
\end{abstract}

Water samples were collected in Middle Amazonia from the Amazon River, Rio Negro and 17 tributaries of Rio Negro. The analyses consisted of $\mathrm{pH}$, conductivity, and dissolved organic (DOC) measurements, as well as plasma source mass spectrometry (ICP-MS). Factor analysis revealed three factors, which explained $94 \%$ of the total variance. A plot of factor scores presented a cluster containing mostly samples from the Rio Negro Basin. Ultrafiltration tests confirmed that organics from the Rio Negro have higher molecular mass than in theAmazon, and that some metals are associated with these compounds. Heavy rare-earth elements (REE) are enriched relative to light REE in the dissolved fraction of most rivers of the Negro Basin; the opposite occurred in suspended matter.

Keywords: Amazonia, Rio Negro (Brazil), blackwater rivers, multivariate analysis, rareearth elements

\section{Introduction}

The Amazon, the world's largest river in terms of watershed, discharge and number of tributaries, receives the name of Solimões, from the Peruvian border to the mouth of the Rio Negro, and from there to the Atlantic Ocean it is called the Amazon. Among the hundreds of tributaries of the Amazon, Rio Negro is considered the most important, because of its discharge. Rio Negro rises as Rio Guainía in the Tunai Slope in Colombia, forms part of the boundary between Colombia and Venezuela and, after flowing for about 1700 $\mathrm{km}$, it flows into the Amazon at Manaus, Brazil. The Negro Basin mostly encompasses an intensely weathered area of Precambrian Shield and extends itself $1100 \mathrm{~km}$ in the eastwest direction and $600 \mathrm{~km}$ in the north-south direction; the basin area, with $715,000 \mathrm{~km}^{2}$, is one of the largest in the world. The chief Negro tributaries are the Uaupés, which rises in central Colombia, and the Branco, which starts at the Brazil-Guyana border. Water level at Manaus usually varies about $7 \mathrm{~m}$ from low to high tide, but a maximum difference of $16 \mathrm{~m}$ is possible. The rainy season is not the same for the whole basin: for example, at Manaus the period goes from January to April, with maximum atmospheric precipitation in March; at Barcelos, about $500 \mathrm{~km}$ in the northwest direction, the rainy period goes from April to June, with maximum precipitation in May. The largest precipitation averages found in the Amazonian region are within the Negro Basin, in Taraquá (3652 mm year ${ }^{-1}$ ) and Iaureté (3506 mm year-1) ${ }^{1}$.

Some characteristics of the Rio Negro are: bed stability, with low erosion; extremely weathered podzolic soil; depleted aquatic fauna and flora; low concentration of dissolved salts and absence of suspended matter; low $\mathrm{pH}$; and an intense color, ranging from dark brown to black, due to high concentrations of humic compounds. The low sediment load permits the high concentrations of humic acid 
and fulvic acid in solution, as humic compounds would adsorb on particles, if present. Amazonian rivers with similar characteristics are called blackwater rivers ${ }^{2,3}$. On the other hand, rivers like the Amazon are called whitewater rivers. Their characteristics are: noticeable bed mobility; high sediment, salt and organic matter load; favorable conditions for aquatic fauna and flora; and water color ranging from colorless to light yellow.

Since the fifties, Amazonian rivers have been the object of many chemical and geochemical studies (for example, Sioli ${ }^{4}$, Stallard and Edmond ${ }^{5}$ and Ertel et al. ${ }^{6}$ ). As a consequence of the limited infrastructure available and the large distances involved, most studies were restricted to the main stem of the Amazon, and a large number were based on samples collected only at Manaus or near the river mouth. Studies on blackwater rivers have been rare, and generally limited to a small number of chemical compounds ${ }^{2,6,7}$. Following previous work on the association of metals and humic compounds of the Negro and Solimões rivers near Manaus ${ }^{8}$, this work reports on the concentration of minor and trace elements in the Negro Basin and makes a comparison with the Solimões. Data evaluation was done by means of cluster and factor analysis. Results of ultrafiltration and other tests are also presented and discussed.

\section{Experimental}

\section{Sampling and pretreatment}

Twenty-five samples were collected during the summers of 1995 and 1997: samples IN1, IP1, RN4, RN5, RS4 and RS5 on February 1995, samples 1-12 on February 1997 and samples 13-19 on March 1997. Most samples came from the Rio Negro or its tributaries, between Manaus and Santa Isabel do Rio Negro (Figure 1); two samples (IN1 and IP1) were from igarapés, or small shallow rivers, and two samples (RS4 and RS5) were collected in the Solimões, near Manaus. Samples were manually collected beneath the surface in 1-Liter acid-washed ${ }^{9}$ polyethylene flasks, rinsed with the water being collected. Field measurements of conductivity and $\mathrm{pH}$ followed established procedures ${ }^{10}$. Samples were filtered $(<0.45$ $\mu \mathrm{m})$ on site, using an all-plastic Millipore filter holder, and stored under refrigeration in acid-washed polyethylene bottles, until further analyses.

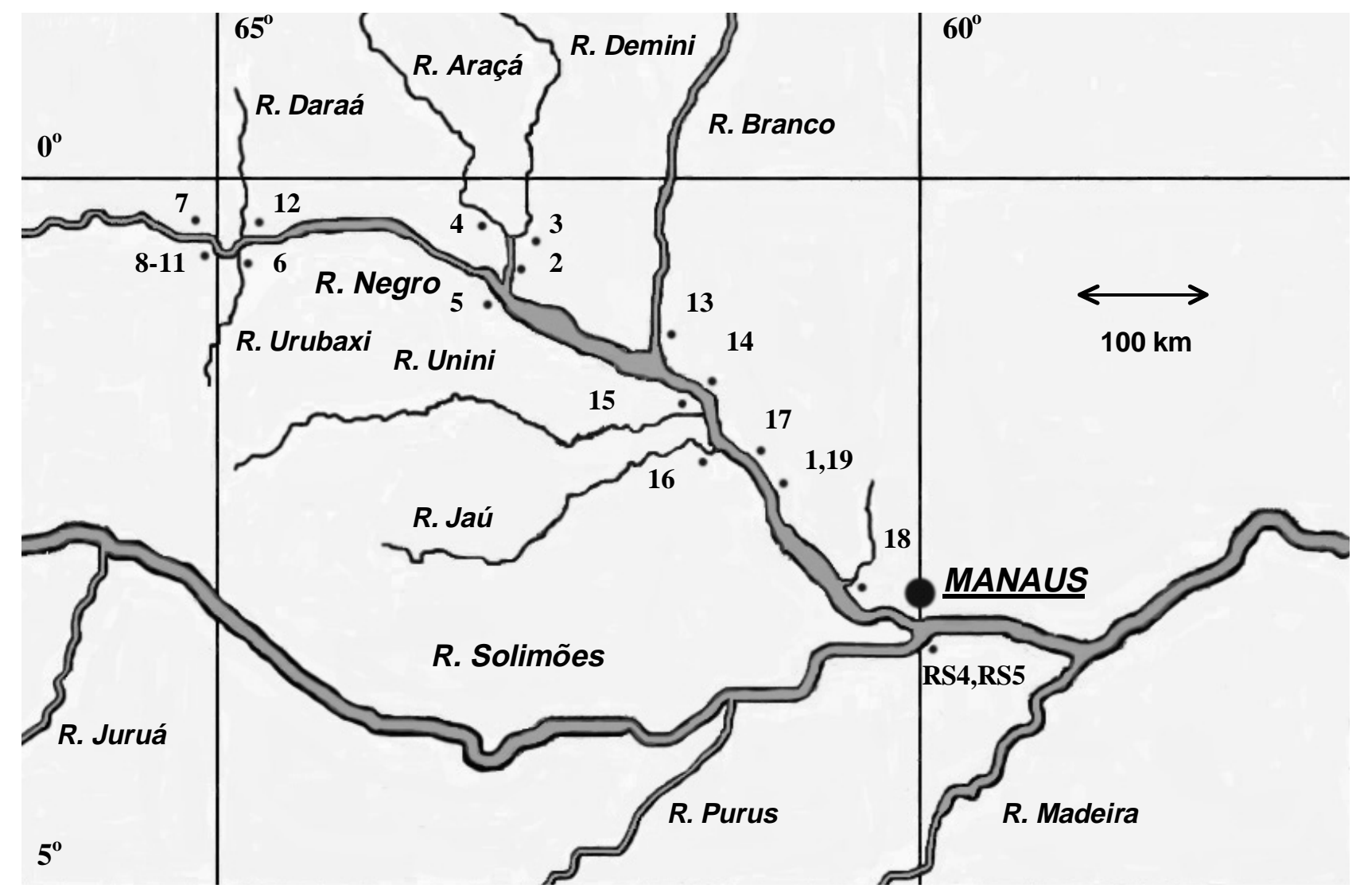

Figure 1. Geographical distribution of sampling sites. (Only some rivers are shown) 


\section{Elementalanalysis}

Total and inorganic carbon in water samples were determined with a Dohrmann DC-190 Carbon Analyzer; dissolved organic carbon (DOC) was obtained by difference. Other elements were determined by inductively coupled plasma mass spectrometry (ICP-MS) using an ELAN 5000 equipment (Perkin-Elmer-Sciex). The sample introduction system was a Meinhard nebulizer connected to a cyclonic spray chamber. Platinum sampler and skimmer were used for better detection limits. Plasma and mass spectrometer operating conditions were optimized daily for the same purpose and for minimizing oxide interferences (e.g., $\left.{ }^{138} \mathrm{Ba}^{16} \mathrm{O}^{+},{ }^{140} \mathrm{Ce}^{16} \mathrm{O}^{+}\right)$. Typically, sensitivity of the in-

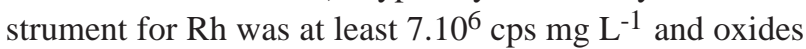
were below $2 \%$. Updating of the response factors was achieved with a $50 \mu \mathrm{g} \mathrm{L}^{-1}$ multielemental solution containing 58 elements, prepared from Perkin-Elmer Standards N930-0232, N930-0233 and N930-0235. Uncertainty of the results was typically $\pm 10 \%$. REE were determined in the quantitative mode; all other elements in the semiquantitative mode (TotalQuant ${ }^{\mathrm{TM}}$ ). Calibration for quantitative REE determination was made by analytical curves $\left(0.5\right.$ to $\left.5 \mu \mathrm{g} \mathrm{L}^{-1}\right)$ prepared from the multielemental solution standard N930-0232. In all cases, correlation coefficients greater than 0.999 were obtained. Isobaric interferences $(\mathrm{Nd}, \mathrm{Sm})$ were corrected using the appropriate elemental equations. Table 1 summarizes some relevant information concerning measuring parameters and quantification levels for REE.

Table 1. Operational parameters in ICP mass spectrometry of rareearth elements. (Numbers beside isotopes are background equivalent concentrations (BEC), expressed in $\mathrm{ng} \mathrm{L}^{-1}$ ).

Mass Spectrometer: ELAN 5000A (Perkin Elmer-Sciex) RF Power: $1050 \mathrm{~W}$

Argon Flow Rates (L. min $^{-1}$ ): Nebulizer - 0.950; Plasma -15.00; Auxiliary - 1.00 .

Internal Standards: ${ }^{115} \mathrm{In},{ }^{205} \mathrm{Tl}$

Isotopes measured: ${ }^{115} \mathrm{In},{ }^{139} \mathrm{La}(5.9),{ }^{140} \mathrm{Ce}(9.4),{ }^{141} \mathrm{Pr}(5.8)$, ${ }^{146} \mathrm{Nd}(7.8),{ }^{152} \mathrm{Sm}(4.9),{ }^{153} \mathrm{Eu}(4.0),{ }^{157} \mathrm{Gd}(4.0),{ }^{159} \mathrm{~Tb}(1.6)$, ${ }^{163} \mathrm{Dy}$ (6.7), ${ }^{165} \mathrm{Ho}(1.7),{ }^{166} \mathrm{Er}(6.4),{ }^{169} \mathrm{Tm}$ (2.5), ${ }^{172} \mathrm{Yb}$ (5.9), ${ }^{175} \mathrm{Lu}$ (2.4), ${ }^{205} \mathrm{~T} 1$.

Measuring Parameters: Scanning mode: normal resolution and peak hopping; Dwell time: $100 \mathrm{~ms}$; sweeps/reading: 1; readings/ replicate: 1 ; number of replicates: 3

\section{Flatmembrane ultrafiltration}

Ultrafiltrations were performed in Amicon 8400 cells (400 ml capacity), employing flat membranes with cut-off levels of 100, 10 and $1 \mathrm{kDa}$ (Amicon YM100, PM10 and YM2, respectively). Samples were previously filtered through

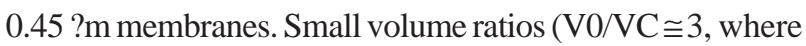

$\mathrm{V0}$ is the initial volume and $\mathrm{VC}$ is the retentate volume) were employed to minimize concentration polarization ${ }^{8}$.

\section{Datatreatment}

The cluster analysis and factor analysis routines of the STATISTICA 5.1 program (StatSoft Inc.) were employed for data reduction and sample classification, following established procedures ${ }^{11}$. Variables with more than two cases under the detection limit, or more than two missing values, were discarded. For the remaining 36 variables, missing values were replaced by the variable average. Before cluster analysis, variables were standardized by means of Z-scores; then squared Euclidean distances were calculated. As for factor analysis, the raw data matrix was introduced in principal component analysis, without any rotation.

\section{Results and Discussion}

Most rivers have high organic carbon (DOC) concentrations, Rio Araçá presenting a maximum of $20.6 \mathrm{mg} \mathrm{L}^{-1}$ and Rio Branco a minimum of $2.7 \mathrm{mg} \mathrm{L}^{-1}$ (Table 2). DOC concentrations in Rio Solimões (7.7-8.6 mg L-1) are near the mean value found in the Negro Basin $\left(11.4 \mathrm{mg} \mathrm{L}^{-1}\right)$. The $\mathrm{pH}$ in the Negro Basin (3.89-6.07) is lower than in Rio Solimões (6.93-6.99); the minimum value of 3.89 was found at Rio Tea. Conductivity ranges from 8.8 to $28.6 \mu \mathrm{S} \mathrm{cm}^{-1}$ in the Negro Basin were lower than the values observed in Rio Solimões (68.8-93.3 $\left.\mu \mathrm{S} \mathrm{cm}^{-1}\right)$. For many sites in the Negro Basin, the hydrogen ion concentration alone can explain most of these low conductivities. There is a significant direct correlation at $99.9 \%$ confidence level between conductivity and DOC $(r=0.859)$ and a converse correlation between DOC and $\mathrm{pH}(\mathrm{r}=-0.755)$ in the Negro Basin. Sediment load $(>0.45 \mu \mathrm{m})$ is extremely low in the Negro Basin, the mean value was found to be $47 \mathrm{mg} \mathrm{L}^{-1}$ for the samples taken in 1997.

The results of cluster analysis are presented as a dendogram, where the similarity of two variables is conversely proportional to the linkage distance (Figure 2). This graph reveals three clusters: cluster I includes variables conductivity, $\mathrm{Cl}, \mathrm{K}, \mathrm{U}, \mathrm{pH}$, as well as alkaline-earth metals; cluster II includes $\mathrm{Rb}$, Th, Ti, Y, Zr and rare-earth elements; and cluster III contains As, DOC, Na, Si, V, Zn and transition metals, like Fe and Mn. Eight variables, representative of a definite chemical group, were selected for factor analysis. This analysis showed the occurrence of three factors with eigenvalues greater than one, accounting for $94 \%$ of the total variance. The main contribution (43.1\% of variance) comes from variables included in 
Table 2. Preliminary analytical results. (ND: not determined).

\begin{tabular}{|c|c|c|c|c|}
\hline Sample & Location & $\mathrm{pH}$ & $\begin{array}{c}\text { DOC } \\
\left(\mu \mathrm{g} \mathrm{L}^{-1}\right)\end{array}$ & $\begin{array}{l}\text { Conductivity } \\
\left(\mu \mathrm{S} \mathrm{cm}^{-1}\right)\end{array}$ \\
\hline IN1 & Igarapé Inácio (near Manaus) & 4.05 & 17.5 & 28.6 \\
\hline IP 1 & Igarapé Paulista (near Manaus) & 4.58 & 4.6 & 10.5 \\
\hline RN4 & Rio Negro (near Manaus) & 5.01 & 7.8 & 9.87 \\
\hline RN5 & Rio Negro (at Manaus) & 5.80 & 7.7 & 8.88 \\
\hline RS4 & Rio Solimões (near Manaus) & 6.93 & 7.7 & 93.3 \\
\hline RS5 & Rio Solimões (at Manaus) & 6.99 & 8.6 & 68.8 \\
\hline 1 & Rio Maependi & 4.14 & 12.6 & 15.6 \\
\hline 2 & Rio Demini (below Araçá) & 3.96 & 14.1 & 14.7 \\
\hline 3 & Rio Demini (above Araçá) & 5.26 & 11 & 13.2 \\
\hline 4 & Rio Araçá & ND & 20.6 & 17.1 \\
\hline 5 & Rio Negro (at Barcelos) & 4.42 & 10.0 & 14.5 \\
\hline 6 & Rio Urubaxi & 4.19 & 9.2 & 14.6 \\
\hline 7 & Rio Marauiá & 5.51 & 6.1 & 9.5 \\
\hline 8 & Rio Tea & 3.89 & 14.7 & 24.4 \\
\hline 9 & Rio Uneiuxi & 4.08 & 12.7 & 21.9 \\
\hline 10 & Rio Negro (at Santa Isabel) & 4.63 & 11.1 & ND \\
\hline 11 & Rio Aiuarã & 4.65 & 9.0 & 18.0 \\
\hline 12 & Rio Daraá & 3.91 & 18.6 & 27.7 \\
\hline 13 & Rio Branco & 6.07 & 2.7 & 10.0 \\
\hline 14 & Rio Juapiris & 5.15 & 9.5 & 10.8 \\
\hline 15 & Rio Unini & 4.54 & 8.7 & 9.9 \\
\hline 16 & Rio Jaú & 4.55 & 7.4 & 12.2 \\
\hline 17 & Rio Camanaú & 5.04 & 10.1 & 10.4 \\
\hline 18 & Rio Cuieras & 5.17 & 7.7 & 8.8 \\
\hline 19 & Rio Maependi & 4.08 & 13.8 & 21.3 \\
\hline
\end{tabular}

Factor I: Ca, conductivity and $\mathrm{Mg}$ (Table 3). Factor II (27.8\% of variance) is composed of $\mathrm{Ti}, \mathrm{Ce}$ and $\mathrm{Th}$, and Factor III (22.7\% of variance) of $\mathrm{Cr}$ and Ni. This grouping is similar to that found in cluster analysis. On a graph of factor scores (Figure 3), most samples of the Negro Basin join a homogeneous group, with moderate scores on factors I and II; this group is supposedly composed only of blackwater samples. On the same graph, samples from Rio Solimões (RS4 and RS5) are located apart from the previous group, because they score high on factor I; on the other hand, samples 3, 7 and 13 score high on factor II. It seems clear from factor analysis that not every river inside the Negro Basin is a 'pure' blackwater one. Rio Branco (sample 13), for example, presents intermediate values between a blackwater and a whitewater river for most elements (Table 4). This characteristic of Rio Branco can be attributed to its steep course, before arriving at the Amazonian plane. Table 5 shows mean values for the elemental analysis of blackwater samples, i.e. samples from the $\mathrm{Ne}$ gro Basin, except samples 3, 7 and 13. As a rule, concentrations of $\mathrm{Al}, \mathrm{Co}$ and $\mathrm{Ni}$ are higher, and of alkaline and alkaline-earth metals and $\mathrm{Si}$ are lower in blackwater rivers than in whitewater ones.

Results of sequential ultrafiltration tests of three blackwater (IN1, IP1 and RN4) and one whitewater sample (RS4) are presented in Table 6. Masses retained in the fractions $>100 \mathrm{kDa}, 10-100 \mathrm{kDa}$ and 1-10 kDa were summed and shown as mass $>1 \mathrm{kDa}$, in comparison to the

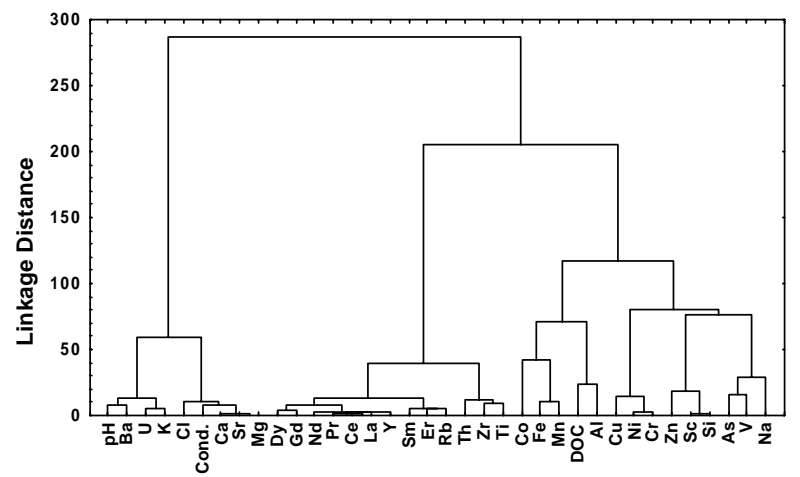

Figure 2. Tree diagram for 36 variables, according to cluster analysis. (Amalgation rule: Ward's method; distance measure: squared Euclidean; variable standardization: Z-scores)

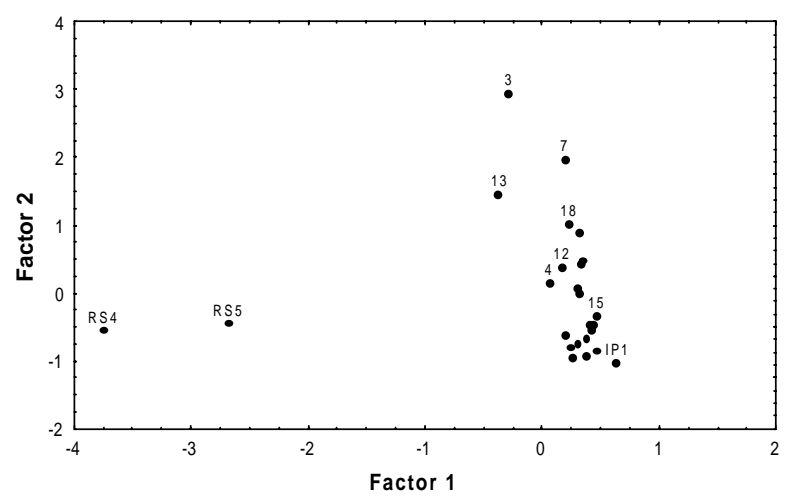

Figure 3. Factor scores on factors I and II. (Extraction method: Principal components; rotation: Varimax raw; 25 cases; variables: $\mathrm{Ca}, \mathrm{Ce}$, conductivity, $\mathrm{Cr}, \mathrm{Mg}, \mathrm{Ni}$, Th and $\mathrm{Ti}$ ) 
Table 3: Factor loadings of variables (Extraction method: Principal components; rotation: Varimax raw; 25 cases)

\begin{tabular}{lccc}
\hline Variable & Factor 1 & Factor 2 & Factor 3 \\
\hline $\mathrm{Mg}$ & -0.979 & 0.056 & 0.047 \\
$\mathrm{Ca}$ & -0.986 & -0.104 & 0.090 \\
$\mathrm{Conductivity}$ & -0.931 & -0.251 & 0.091 \\
$\mathrm{Ti}$ & 0.064 & 0.928 & -0.118 \\
$\mathrm{Ce}$ & 0.121 & 0.935 & -0.043 \\
$\mathrm{Th}$ & 0.094 & 0.930 & 0.033 \\
$\mathrm{Cr}$ & 0.097 & 0.014 & -0.984 \\
$\mathrm{Ni}$ & 0.072 & 0.073 & -0.982 \\
\hline
\end{tabular}

Table 4: Elemental water analysis of samples RS4 and RS5 (Rio Solimões), RN5 (Rio Negro) and 13 (Rio Branco) (Concentrations in $\mathrm{mg} \mathrm{L}^{-1}$; ND: not determined).

\begin{tabular}{|c|c|c|c|c|}
\hline & RS4 & RS5 & RN5 & 13 \\
\hline $\mathrm{Na}$ & ND & $3.2 \times 10^{3}$ & $4.8 \times 10^{2}$ & $1.09 \times 10^{3}$ \\
\hline $\mathrm{Mg}$ & $1.14 \times 10^{3}$ & $9.1 \times 10^{2}$ & 142 & $4.1 \times 10^{2}$ \\
\hline Al & 24 & 55 & 111 & 121 \\
\hline $\mathrm{Si}$ & $1.55 \times 10^{3}$ & $1.43 \times 10^{3}$ & $1.08 \times 10^{3}$ & $4.0 \times 10^{3}$ \\
\hline $\mathrm{K}$ & $6.6 \times 10^{2}$ & $5.8 \times 10^{2}$ & $3.0 \times 10^{2}$ & $7.6 \times 10^{2}$ \\
\hline $\mathrm{Ca}$ & $9.3 \times 10^{3}$ & $7.1 \times 10^{3}$ & $4.2 \times 10^{2}$ & $7.0 \times 10^{2}$ \\
\hline $\mathrm{Ti}$ & 0.96 & 0.91 & 0.48 & 8.0 \\
\hline V & 1.0 & 0.85 & 0.32 & 1.1 \\
\hline $\mathrm{Cr}$ & 0.11 & 0.21 & 0.10 & 8.9 \\
\hline $\mathrm{Mn}$ & 4.4 & 9.0 & 10.7 & 3.4 \\
\hline $\mathrm{Fe}$ & 135 & 173 & $2.2 \times 10^{2}$ & $2.5 \times 10^{2}$ \\
\hline $\mathrm{Co}$ & 0.04 & 0.06 & 0.14 & 0.59 \\
\hline $\mathrm{Ni}$ & 0.62 & 0.54 & 0.21 & 43 \\
\hline $\mathrm{Cu}$ & 3.8 & 3.7 & 0.42 & 5.1 \\
\hline $\mathrm{Zn}$ & 2.4 & 0.80 & 2.7 & 121 \\
\hline $\mathrm{Ga}$ & 0.04 & 0.03 & 0.01 & 0.07 \\
\hline As & 0.95 & 0.76 & 0.11 & 1.8 \\
\hline $\mathrm{Rb}$ & 1.4 & 1.3 & 1.3 & 3.9 \\
\hline $\mathrm{Sr}$ & 56 & 43 & 4.8 & 15 \\
\hline $\mathrm{Y}$ & 0.13 & 0.17 & 0.13 & 0.43 \\
\hline $\mathrm{Zr}$ & 0.03 & 0.04 & 0.05 & 0.25 \\
\hline $\mathrm{Ba}$ & 30 & 23 & 8.1 & 24 \\
\hline $\mathrm{La}$ & 0.10 & 0.15 & 0.18 & 0.49 \\
\hline $\mathrm{Ce}$ & 0.22 & 0.33 & 0.54 & 1.3 \\
\hline $\mathrm{Pr}$ & 0.03 & 0.04 & 0.06 & 0.14 \\
\hline $\mathrm{Nd}$ & 0.11 & 0.17 & 0.19 & 0.44 \\
\hline $\mathrm{Sm}$ & 0.05 & 0.06 & 0.04 & 0.13 \\
\hline $\mathrm{Eu}$ & 0.02 & 0.02 & 0.01 & 0.02 \\
\hline Gd & 0.05 & 0.06 & 0.04 & 0.08 \\
\hline Dy & 0.03 & 0.04 & 0.03 & 0.06 \\
\hline $\mathrm{Er}$ & 0.02 & 0.02 & 0.02 & 0.06 \\
\hline $\mathrm{Pb}$ & 0.19 & 0.27 & 0.16 & 0.25 \\
\hline $\mathrm{Th}$ & 0.02 & 0.04 & 0.07 & 0.10 \\
\hline $\mathrm{U}$ & 0.09 & 0.09 & 0.04 & 0.10 \\
\hline
\end{tabular}

filtered mass $(<1 \mathrm{kDa})$. For example, in blackwater samples there is a higher proportion of organic compounds with molecular mass $>1 \mathrm{kDa}$, i.e. humic compounds, than in Rio Solimões (Figure 4a). This result agrees with a previous ultrafiltration study of the Rio $\mathrm{Negro}^{8}$. Other metals, such as $\mathrm{Al}, \mathrm{Ba}, \mathrm{Ca}, \mathrm{Mg}$ and $\mathrm{Mn}$ (Figure 4b) are partitioned similarly, suggesting an association with humic compounds in blackwater samples. For most elements, however, partition is the same in blackwater and whitewater samples
Table 5: Elemental water analysis of blackwater samples. (Concentration in $\mathrm{mg} \mathrm{L}^{-1}$; $\mathrm{NC}$ : not calculated; $\mathrm{N}$ : number of averaged samples)

\begin{tabular}{|c|c|c|c|c|c|}
\hline & Maximum & Minimum & Mean & Std. Dev. & $\mathrm{N}$ \\
\hline $\mathrm{Na}$ & $1.64 \times 10^{3}$ & 114 & $4.0 \times 10^{2}$ & $3.2 \times 10^{2}$ & 20 \\
\hline $\mathrm{Mg}$ & 171 & 20 & 73 & 47 & 20 \\
\hline Al & $2.4 \times 10^{2}$ & 89 & 161 & 48 & 20 \\
\hline $\mathrm{Si}$ & $3.0 \times 10^{3}$ & $6.3 \times 10^{2}$ & $1.57 \times 10^{3}$ & $5.9 \times 10^{2}$ & 20 \\
\hline $\mathrm{S}$ & $9.1 \times 10^{3}$ & $<1.8 \times 10^{3}$ & $\mathrm{NC}$ & $\mathrm{NC}$ & - \\
\hline $\mathrm{Cl}$ & $4.7 \times 10^{3}$ & $<5.5 \times 10^{2}$ & $\mathrm{NC}$ & $\mathrm{NC}$ & - \\
\hline $\mathrm{K}$ & $3.5 \times 10^{2}$ & 55 & $2.0 \times 10^{2}$ & 96 & 20 \\
\hline $\mathrm{Ca}$ & $6.8 \times 10^{2}$ & 37 & 179 & 154 & 20 \\
\hline $\mathrm{Ti}$ & 4.8 & 0.33 & 2.2 & 1.4 & 20 \\
\hline $\mathrm{V}$ & 3.8 & 0.09 & 0.56 & 0.78 & 20 \\
\hline $\mathrm{Cr}$ & 15.3 & 0.06 & 2.9 & 4.4 & 20 \\
\hline $\mathrm{Mn}$ & 16.9 & 2.5 & 7.8 & 4.1 & 20 \\
\hline $\mathrm{Fe}$ & $3.4 \times 10^{2}$ & 47 & 189 & 74 & 20 \\
\hline $\mathrm{Co}$ & 8.3 & 0.05 & 0.73 & 1.8 & 20 \\
\hline $\mathrm{Ni}$ & 114 & 0.09 & 15 & 28 & 20 \\
\hline $\mathrm{Cu}$ & 9.7 & 0.2 & 1.3 & 2.1 & 20 \\
\hline $\mathrm{Zn}$ & 39 & 2.7 & 7.9 & 8.8 & 20 \\
\hline $\mathrm{Ga}$ & 0.10 & 0.01 & 0.04 & 0.02 & 20 \\
\hline As & 1.8 & $<0.02$ & 0.38 & 0.52 & 18 \\
\hline $\mathrm{Rb}$ & 2.0 & 0.2 & 1.0 & 0.6 & 20 \\
\hline $\mathrm{Sr}$ & 7.5 & 0.4 & 2.9 & 1.9 & 20 \\
\hline $\mathrm{Y}$ & 0.28 & 0.05 & 0.15 & 0.06 & 20 \\
\hline $\mathrm{Zr}$ & 0.28 & 0.02 & 0.12 & 0.07 & 20 \\
\hline I & 0.42 & 0.06 & 0.22 & 0.08 & 20 \\
\hline $\mathrm{Ba}$ & 21 & 2.8 & 8.3 & 4.5 & 20 \\
\hline $\mathrm{La}$ & 0.43 & 0.08 & 0.21 & 0.09 & 19 \\
\hline $\mathrm{Ce}$ & 1.0 & 0.29 & 0.57 & 0.23 & 20 \\
\hline $\mathrm{Pr}$ & 0.11 & 0.03 & 0.06 & 0.02 & 20 \\
\hline $\mathrm{Nd}$ & 0.40 & 0.10 & 0.23 & 0.09 & 20 \\
\hline $\mathrm{Sm}$ & 0.08 & 0.02 & 0.05 & 0.02 & 20 \\
\hline $\mathrm{Eu}$ & 0.02 & $<0.004$ & 0.01 & 0.002 & 18 \\
\hline $\mathrm{Gd}$ & 0.09 & 0.02 & 0.04 & 0.02 & 20 \\
\hline Dy & 0.06 & 0.01 & 0.03 & 0.01 & 20 \\
\hline $\mathrm{Er}$ & 0.04 & 0.01 & 0.02 & 0.01 & 20 \\
\hline $\mathrm{Pb}$ & 0.65 & 0.07 & 0.21 & 0.14 & 20 \\
\hline $\mathrm{Th}$ & 0.17 & 0.01 & 0.07 & 0.05 & 20 \\
\hline $\mathrm{U}$ & 0.07 & $<0.004$ & 0.03 & 0.02 & 19 \\
\hline DOC & $2.06 \times 10^{4}$ & $4.6 \times 10^{3}$ & $1.14 \times 10^{4}$ & $4.2 \times 10^{4}$ & 20 \\
\hline
\end{tabular}

Dissolved REE concentrations in blackwater rivers are generally in the range of $0.1-1 \mathrm{mg} \mathrm{L}^{-1}$ for $\mathrm{La}, \mathrm{Ce}$ and $\mathrm{Nd}$, and below $0.1 \mu \mathrm{g} \mathrm{L}^{-1}$ for the other REE; concentrations are even lower in Rio Solimões (Tables 4 and 5). Graphs of REE in solution, normalized to the NASC average shale standard ${ }^{12}$, show an almost horizontal line for a typical blackwater sample (RN5), except for the small enrichment of Ce; samples from Rio Solimões (RS5) present a bellshaped curve (Figure 5). However, if samples from Solimões are normalized against a chondrite standard ${ }^{13}$, a typical horizontal line is found (Figure 6). These patterns indicate that the composition of blackwaters is similar to shales, while that of whitewaters is more alike to chondrites. Similar results are obtained with graphs of suspended matter.

The ratio of the NASC normalized concentrations of $\mathrm{La}$ to $\mathrm{Yb},(\mathrm{La} / \mathrm{Yb})_{\mathrm{N}}$, has been used as a measure of enrichment of light to heavy REE ${ }^{14}$. Samples RS4 and RS5 from Rio Solimões have values around 1.0, both in solution 


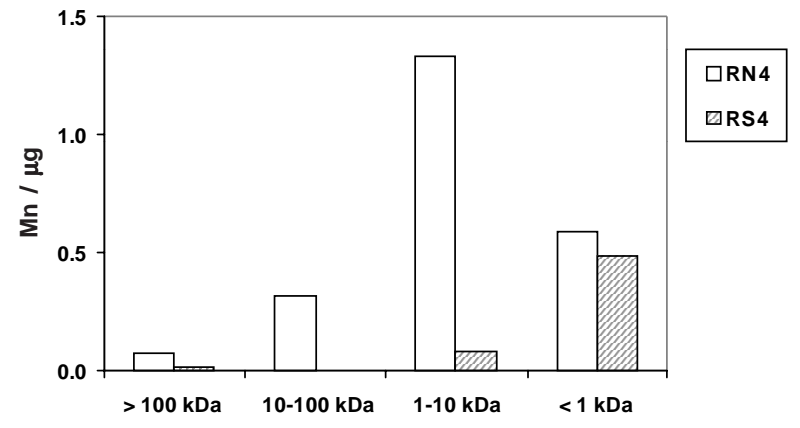

(a)

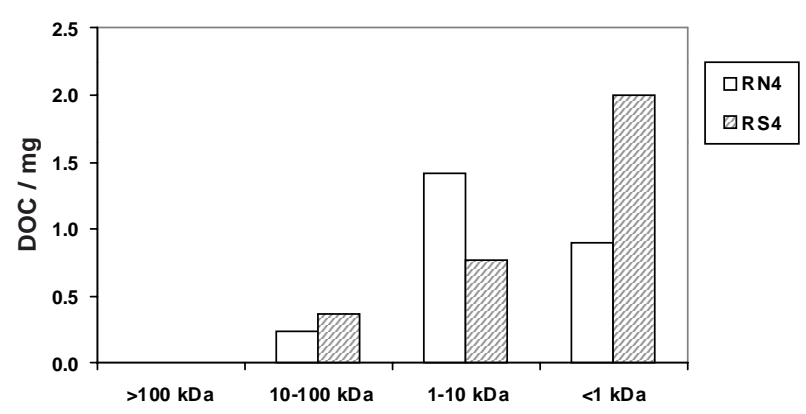

(b)

Figure 4. Mass distribution of manganese (a) and DOC (b) in samples RN4 (Rio Negro) and RS4 (Rio Solimões), after ultrafiltration. (Volume ratios $\cong 3$ )
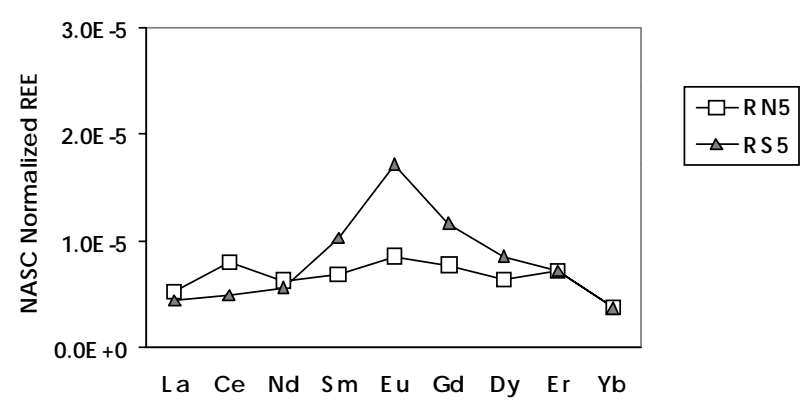

(a)

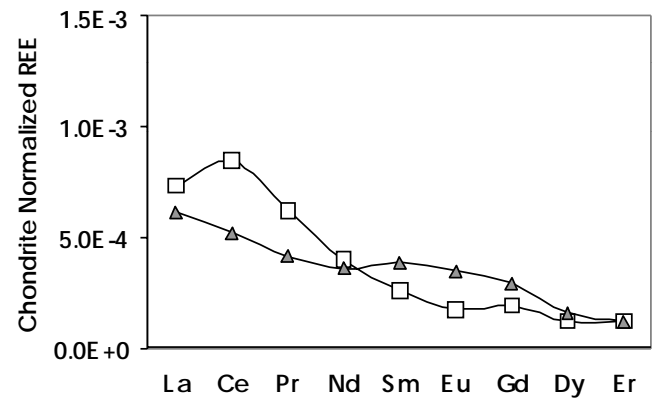

(b)

Figure 5. Rare-earth Elements in samples RN5 (Rio Negro) and RS5 (Rio Solimões) normalized against a) NASC and b) Chondrite.

Table 6 : Analytical results from the ultrafiltration of three blackwater samples (IN1, IP1, and RN4) and a whitewater sample (RS4). (Mass of elements in $\mathrm{mg}$ )

\begin{tabular}{|c|c|c|c|c|c|c|c|c|}
\hline & \multicolumn{2}{|c|}{ IN 1} & \multicolumn{2}{|c|}{ IP 1} & \multicolumn{2}{|c|}{ RN4 } & \multicolumn{2}{|c|}{ RS4 } \\
\hline & $>1 \mathrm{kDa}$ & $<1 \mathrm{kDa}$ & $>1 \mathrm{kDa}$ & $<1 \mathrm{kDa}$ & $>1 \mathrm{kDa}$ & $<1 \mathrm{kDa}$ & $>1 \mathrm{kDa}$ & $<1 \mathrm{kDa}$ \\
\hline $\mathrm{Mg}$ & 4.9 & 1.2 & 3.3 & 2.0 & 18.2 & 7.0 & 25 & 208 \\
\hline $\mathrm{Al}$ & 48.3 & 4.2 & 15.3 & 3.0 & 25.6 & 2.7 & 1.6 & 3.1 \\
\hline $\mathrm{Si}$ & 5 & 124 & 17 & 160 & 4 & 187 & 10 & 315 \\
\hline K & 15 & 17 & 12 & 19 & 31 & 48 & 8 & 135 \\
\hline $\mathrm{Ca}$ & 17 & 7 & 14 & 12 & 50 & 24 & 294 & 1662 \\
\hline $\mathrm{Ti}$ & 0.20 & 0.01 & 0.06 & 0.03 & 0.03 & 0.07 & 0.05 & 0.09 \\
\hline $\mathrm{V}$ & 0.03 & 0.00 & 0.01 & 0.01 & 0.03 & 0.02 & 0.03 & 0.14 \\
\hline $\mathrm{Mn}$ & 1.16 & 0.22 & 0.39 & 0.20 & 1.72 & 0.59 & 0.10 & 0.48 \\
\hline $\mathrm{Fe}$ & 28.4 & 3.5 & 19.5 & 3.9 & 34.8 & 2.4 & 9.8 & 5.1 \\
\hline $\mathrm{Co}$ & 0.02 & 0.00 & 0.01 & 0.01 & 0.03 & 0.01 & 0.00 & 0.01 \\
\hline $\mathrm{Rb}$ & 0.05 & 0.04 & 0.04 & 0.05 & 0.15 & 0.14 & 0.02 & 0.27 \\
\hline $\mathrm{Sr}$ & 0.12 & 0.04 & 0.09 & 0.06 & 0.59 & 0.26 & 1.78 & 9.83 \\
\hline $\mathrm{Ba}$ & 0.94 & 0.15 & 0.49 & 0.23 & 1.02 & 1.14 & 1.30 & 4.84 \\
\hline $\mathrm{Ce}$ & 0.16 & 0.01 & 0.07 & 0.01 & 0.14 & 0.01 & 0.03 & 0.00 \\
\hline $\mathrm{Nd}$ & 0.06 & 0.01 & 0.03 & 0.01 & 0.07 & 0.01 & 0.02 & 0.00 \\
\hline $\mathrm{Pb}$ & 3.1 & 0.3 & 2.2 & 0.5 & 8.0 & 1.1 & 0.93 & 0.32 \\
\hline DOC & $2.9 \times 10^{3}$ & $5 \times 10^{2}$ & $4 \times 10^{2}$ & $4 \times 10^{2}$ & $1.7 \times 10^{3}$ & $9 \times 10^{2}$ & $1.1 \times 10^{3}$ & $2.0 \times 10^{3}$ \\
\hline
\end{tabular}

and in suspended matter, indicating that there is no enrichment (Table 7). On the other hand, an enrichment of heavy REE in comparison to light REE is observed in the dissolved fraction of most rivers of the Negro Basin, with ratios well below 1.0; the opposite occurs in the sediment. This enrichment happens because heavy REE form stronger complexes with humic compounds in solution than do the light REE ${ }^{13}$. Rivers of the Negro Basin do not show the same REE pattern as Rio Solimões; instead, their high REE concentrations suggest a similarity to the diluted rivers of low pH described by Goldstein and Jacobsen ${ }^{14}$.

The mixing of Rio Negro with Rio Solimões begins at Manaus and extends itself downstream for about $100 \mathrm{~km}$. From the conductivities of samples collected at the mixing point (Sample RS5) and upstream (samples RN5 and RS4), and considering conductivity conservative, a dis- 
Table 7: NASC normalized ratios of Lanthanum to Ytterbium $(\mathrm{La} / \mathrm{Y})_{\mathrm{N}} \cdot(\mathrm{NC}$ : not calculated)

\begin{tabular}{ccc}
\hline & $(\mathrm{La} / \mathrm{Y})_{\mathrm{N}}$ in Solution & $(\mathrm{La} / \mathrm{Y})_{\mathrm{N}}$ on Filter \\
\hline RS4 & $\mathrm{NC}$ & 0.92 \\
RS5 & 1.18 & 1.02 \\
RN5 & 1.41 & 4.16 \\
1 & 0.32 & 1.34 \\
2 & 0.38 & $\mathrm{NC}$ \\
3 & 081 & 3.02 \\
4 & 0.49 & $\mathrm{NC}$ \\
5 & 0.82 & $\mathrm{NC}$ \\
6 & 0.36 & $\mathrm{NC}$ \\
7 & 0.56 & 0.93 \\
8 & 0.31 & $\mathrm{NC}$ \\
9 & 0.39 & $\mathrm{NC}$ \\
10 & 0.60 & $\mathrm{NC}$ \\
11 & 0.51 & $\mathrm{NC}$ \\
12 & 0.85 & $\mathrm{NC}$ \\
13 & 0.57 & 1.50 \\
14 & 0.82 & $\mathrm{NC}$ \\
15 & 1.01 & $\mathrm{NC}$ \\
16 & 0.49 & $\mathrm{NC}$ \\
17 & 0.69 & 2.20 \\
18 & 0.90 & $\mathrm{NC}$ \\
19 & 0.96 & \\
\hline
\end{tabular}

charge ratio of 2.4:1 (Solimões to Negro) was calculated. This result is similar to the discharge ratios of $2.7: 1^{3}$ and 3.5:1 ${ }^{6}$, obtained from the literature. Sample RS5 seems to be a linear combination of samples RN5 and RS4, based on the discharge ratio (see Table 4). For most elements the difference between the calculated and the measured value is less than 20\%; greater differences can be attributed, in general, to the measurement uncertainty.

\section{Conclusions}

According to factor analysis, most samples of the Rio Negro Basin form a homogeneous blackwater group, with characteristics that differentiate them from the whitewater Rio Solimões; the exceptions, like Rio Branco, present intermediate values between blackwater and whitewater for most variables. This classification does not depend only on variables included in Factor I (Ca, conductivity, etc.), since Factors II and III together explain 50\% of the variance.

Conductivity in blackwater rivers is a function of the organic carbon concentration, as indicated by the good correlation between both parameters. In whitewater rivers the main contribution comes from dissolved inorganic ions. According to ultrafiltration tests, Rio Solimões presents mostly low molecular mass organics, whereas in Rio Negro there is a higher proportion of humic compounds.
Some properties of blackwater rivers, such as the distribution pattern of some elements in ultrafiltration experiments and the enrichment of heavy REE in the dissolved fraction seem to be related to the concentration of humic compounds.

\section{Acknowledgements}

This study received financial support from the National Research Council of Brazil (CNPq), from FINEP, from FAPERJ and from the National Science Foundation. Thanks are due also to our laboratory technicians M. Dupin and A. J. Pereira (PUC/RJ) for assistance in sample analysis and to T. Pimentel (INPA) and the crew of the Amanaí boat, for helping in fieldwork.

\section{References}

1. DNPVN. Vias navegáveis interiores do Brasil. Vol. 4 - Estudo Geral: Bacia Amazônica; Dep. Nac. de Portos e Vias Navegáveis; Rio de Janeiro, s.d.

2. Leenheer, J. A.; Santos, U. M. ActaAmazonica 1980, 10, 343.

3. Hedges, J. I.; Cowie, G. L.; Richey, J. E., Quay, P. D.; Benner, R.; Strom, M.; Forsberg, B. R. Limnol. Oceanogr. 1994, 39, 743.

4. Sioli, H. Forsch. Fortsch. 1950, 25, 274.

5. Stallard, R. F.; Edmond, J. M. J. Geophys. Research 1983, 88, 9671.

6. Ertel, J. R.; Hedges, J.; Devol, A. H.; Richey, J. E.; Ribeiro, M. N. G. Limnol. Oceanogr. 1986, 31, 739.

7. Williams, P. M. Nature 1968, 218, 937.

8. Küchler, I. L.; Miekeley, N.; Forsberg, B. Sci. Total Environ. 1994, 156, 207.

9. Moody, J. R.; Lindstrom, R. M. Anal. Chem. 1977, 49, 2264.

10. Eaton, A. D.; Clesceri, L. S.; Greenberg, A. E., Eds. Standard Methods for the Examination of Water and Wastewater, $19^{\text {th }}$ Ed. American Public Health Association; Washington, 1995. p. 2-46 and 4-68.

11. Dillon, W. R.; Goldstein, M. Multivariate analysis: Methods and applications; Wiley; New York, 1984.

12. Elderfield, H.; Upstill-Goddard, R.; Sholkowitz, E. R. Geochim. et Cosmochim. Acta 1990,54, 971.

13. Evensen, N. M.; Hamilton, P. J.; O’Nions, R. K. Geochim.Cosmochim. Acta 1978, 42,1199.

14. Goldstein, S. J.; Jacobsen, S. Earth Planet. Sci. Lett. 1988, 89, 35. 